inclined to take issue with his proposal that boards of directors be placed in charge of rate and labor matters. In his historical treatment of mechanical and engineering progress the author is at his best. Had he confined himself to that feld, he would have produced a volume of much greater readability and value.

Taken as a whole, the book bears evidence of being the product of a number of years' work, the final writing being done from notes, many of which were not revised to accord with the latest available facts. Even so, there is much of worth scattered through the volume, and the general student of railway history will find it a convenient reference book on many topics.

J. H. P.

\section{中}

Danger Sianals for Teachers. By Dr. A. E.

Winship. Chicago: Forbes and Company, 1919. Pp. 204.

Few among those practically interested in education have ever heard Dr. Winship speak without wishing that he would put more of his red-blooded common sense and democracy into black and white. In so doing in his "Danger SignaIs for Teachers," I am sure he has greatly multiplied the reach of some of the most worthwhile things he has yet said.

In sharp and striking paragraphs, short chapters and big print, he has simply and dramatically forced upon teachers existing factors in American life and education which make for a completer and truer democracy. The demand created by the war for statesmen in education, skill in teaching as the discovering of how a pupil can "dig in," his chapter on "Don't Be Aristocratic," his advocacy of the throwing of all individuals into solution through music, recreation and the drama, his insistence on democracy "for the Cabots, and Lowells as much as for the Lenines and the Trotzkys," the out-of-dateness of the politician in educationall will impress and help the common citizen who ought to be interested in educational issues, quite as much as those to whom it is a professional duty to be interested. That although the book reached me at eleven o'clock at night, I read it through before $I$ went to bed and that $I$ intend to read it through again is the best testimony I can offer of the extent to which it interested me.

\section{A. Duncan Yocem.}

\section{$\$$}

The Healis of the Teacher. By Dr. William Estabrook Chancellor. Chicago, Ill.: Forbes and Co. Pp. 307.

Everything that Dr. Chancellor writes is remarkable-not merely in the sense of being noteworthy, but in that of being unusual. It is not so much that he writes in unexpected fields, as that in anything he writes, he is certain to discover new leads and to give his readers new points of view. All this is true of his new book on "The Health of the Teacher." It treats of everything from the care of the hair to being too successful and obliging or excessively anxious about health. Since it is as practical as it is interesting, it is sure to do much good to its readers in general and to teachers in particular.

A. Duncan Yocum.

\title{
II. REVIEWS OF REPORTS
}

Efficiency and Economy in California.--Students of public affairs will welcome from the state of California the report of the committee on efficiency and economy. The committee appointed by Governor Stephens on November 25,1918 , was composed of eleven men prominent in the official and civic life of the state, and carried on its work through five subcommittees under the chairmanship of Mr. John S. Chambers, Mr. Frank P. Flint, Dr. John R. Haynes, Mr. Marshall DeMotte, and Mr. Edward A. Dickson, respectively. With each subcommittee were associated several eminent men and women representing professional interest, technical skill, and civic understanding. For example the committee on finance, of which $\mathrm{Mr}$.
Chambers was chairman, included among others Mr. Anderson, a banker, Mr. Mclaughlin, labor commissioner, Mr. Hatfield, professor of accounting, and Mr. Plehn, professor of finance, at the state university, and Professor West of Leland Stanford. Expert and lay opinions were wisely blended in formulating the organization and work program of each proposed department.

The committee early found it impossible or undesirable to attempt a general consolidation that would include absolutely all agencies of state administration. Eight elective officers were eliminated at the outset from consideration. The commission also left out of the proposed administrative structure, the civil service commission, the boards concerned with professional 